\title{
ENGLISH LEXICAL LOANWORDS IN INDONESIAN: EXPLORING IN TOURISM MAGAZINE
}

\author{
$\underline{\text { Tatu Siti Rohbiah }}$ \\ UIN SMH Banten \\ tatu.siti.rohbiah@uin.ac.id
}

\begin{abstract}
The aim of this research is to know English lexical loanwords into Indonesian languages in tourism magazine. In this research, the writer uses descriptive qualitative method where she describes the corpus of English lexical loanwords into Indonesian languages in tourism magazine, suc as 9 loanwords from three tourism magazines of English lexical such as Intisari, Tamasya and Jalan-Jalan. The loanword of English lexical is not entirely derived from English itself but from French, Dutch, Latin and others. In tourism magazines use the loanword of English because of prestige. The English loanword made in Indonesian has more prestige.
\end{abstract}

Keywords: English lexical, loanwords, and tourism

\section{A. INTRODUCTION}

Human beings as a part of the culture cannot be disassociated with others, because they are closely related to society. What they do or work is named as the culture; its result can be cultivated or accepted by the others. In globalization era, the developing of culture has been effected by the language development. Language itself is a system of arbitrary vocal symbol used by human being for cooperation, communication and identification of himself Yule (2010). Moreover, language is a basic tool of communication, it is an important thing in human life; it represents a basic need of people. Every comunication with other, of course that happens to lexical of Indonesian especially as result of knowledge and technology development, and using register marks. It can be defined either narrowly or broadly, but it is narrowly and commonly perceived as jargon such as the tourism fields.

Moreover, a person uses a language to express his idea and feeling. It is the basic function of language as a mean for communication and interaction with the others. The language plays important role of each aspect in the life, whereas, that the people have many activities in their life, so the meaning of communication of the language has many varieties like health, economics, political languages, etc. This is named as register; it is the part of language variety. Haliday $(1970,1990)$ drew a primary distinction between two types of language variety: the first is dialect defining as variety according to the user and the second is register defining as variety according to the use (Hudson, 1980:48). So, register is a specific vocabulary associated 
with different occupational groups. Each register has its term. That may be taken from the foreign words.

Using a new term from foreign language, which the people often do, that can be seen in many scientific fields such as economics, politics, medicine, tourism etc. The new terms borrowed by Indonesian words are almost taken from English terms. There are also many borrowing terms from other languages like Dutch, French, Latin, Arab, etc. In this case, it occurs because borrowing is easier than creating a new language. As the writer concerns, this paper discusses tourism register Indonesia words borrowed from English words. English is the international language used commonly in modern era. Immediately, Indonesian accepts the English words, both their forms and spelling, while there are words forms of borrowing term that a spelling is same as the Indonesian language.

In this research, the writer would like to limit the discussion on English loan words accepted as Indonesian words: exploring in tourism magazine. The writer uses descriptive qualitative method where she describes the corpus of English loan words of Indonesian word in lexical tourism in magazine.

\section{Language Contacts}

As the part of culture, language has enough concepts and signs to clarify many activities weather it is spiritually or materially, and then the people consider them as a human language (Haliday, 1968:41).

English into Indonesian language obviously has added concepts and signs within Indonesian. It is named as language contacts between Indonesian and English. Many terms of English or Indonesia get language contacts. A language contact is a relation of language that happened between a human language and other human languages (Samsuri, 1981:661).

This language contacts will happen in mutual affected both direct and indirectly among the languages that are mutual related. The causes of the language contact are language changes, and then it becomes a part of human language obviously which will be noted of a history language development itself (Mackey, 1968:554).

It has been estimated that the English contains more than a million words, of which fewer than half are included in unabridged dictionaries; English has been a prodigious borrowed of words that is in our languages. This has come through invasions, immigrations, explorations, trade, and other avenues of contact between English and some foreign language. Here there are many processes of word formation, as Holmes (2000) has pointed out: (1). Sources of the new words, borrowings or adoptions, this process is to be expected in the light of the English disposition to borrow words from other languages in the 
past; (2) self-explaining compound, it is simply the joining of two or more words into a single word; (3) coinages, it is a considerable number of new words must be attributed to deliberate invention or coinage. There has probably never been a time when the creative impulse has not spent itself occasionally in inventing new words, but their chances of general adoption now are often creased by a campaign of advertising as deliberate as the effort

\section{Borrowings}

When speaker of one language borrows words from another language, the foreign word come to be used as regular vocabulary item, it is called by borrowing. For example, when a speaker of English says, "they have a great deal of savoir-faire," this word savoir-faire was originally a borrowed word (or loanword) from French, but it has come to be used as a vocabulary item in English (Akmajian.et all, 1995:225) It is considered that borrowing is different from code switching, which assumes mastery, or two or more languages and the use of a wide range of rules of the languages is to be switched. By contrast, borrowing usually involves the adaptation of a word into phonetic and grammatical system of the other language.

According to Wardhaugh (1986:188), Borrowings are the part of language changes in study of sociolinguistics. He has stated; there are two kinds of language change which created them; (3) blending, it is fusion of two words into one, usually the first part of one word with the last part of another; (4) common words from proper names, it is the common words from proper names have been derived in the past; they are the names of persons, places and brands; dan Employing an old word is a new sense sometimes extends from old words with new meaning, the resource of the vocabulary within

such as internal and external, internally changes include in phonology, morphology and syntax, while externally change is brought through borrowings. Changes that occur through borrowing from other dialects or languages are often quite clearly distinguishable, for while at least, from changes that come internally.

The borrowing is a form that has spread from one linguistic variety (the source) into another variety (the target), it is nearly synonymous with 'loanword,'(Mestrhrie, 2001:432) but the borrowing is often really a stem (smaller than a word), and maybe phrase (large than a word).

Borrowing words from other languages are also important thing in analyzing a new word. The borrowing occurs when one language adds to its own lexicon, a word or morpheme from another language. The borrowed words, of course, remain in the source language or donor, so there is no need to be 
returned. Most languages are borrower.

So, the lexicon can be divided into native and non-native words. The native one is the word that is seen based on history or etymology. While, non-native word is loanwords, or borrowed that are imported from another language (Fromkin, 1974:459).

The language can grow up in globalization era. This indicates that the languages are living, and the language can change by time. Its change is very protruding in lexical or words. So, day by day as many as the words can be added. For instance, the word terminal, nowadays that word has given in an Indonesian lexical, and also there are many lexical borrowings from other languages such as tiket, bagasi, etc. Expropriation of English lexical into Indonesian languages is the process of language contacts between English and Indonesia languages. For this reason, borrowings played an important role in sociolinguistics; the foreign language borrowings in the society borrow the language, which language symbol association that is borrowed in a contact situation causes it (Marcellino, 1996:15).

Indonesia has many languages; it is more than one kind. It is caused that there are language contacts between Indonesian and other languages or foreign languages, so then Indonesian people can use the languages more than one such as English, Dutch, Arabic, etc. So that it is caused by borrowings of language. Indonesian people borrow foreign languages, because they have got domination of foreign language and the presence of language contacts; it is called as bilingual. Usually, in language borrowings are mostly borrowed from Dutch, Arabic and English, especially in Indonesia languages of definite fields, such as in tourism field.

Many Indonesian people use Dutch as their foreign languages. It seems from the history of war by long time ago. Dutch colonized and lived in Indonesia for several hundred years ago. Dutch is learned by Indonesia as language authority, and then this is difference from the other people that has learned Arabic and English languages. Indonesian people have learned Arabic because of religious contact. In long time ago, Arabian people came to Indonesia to bring Islam. They guided Indonesian about Islam. Because of that, Arabic was known and used by Indonesian people.

This is same as Old English. When Christian had introduced to English on 597, Christian has come to English, and also Latin. Even though, it did not mean as the first contact for Old English and Latin at the time, because before it had happened in twice contacts with Latin languages.

Baugh (1935:86-96) has also pointed out that Old English and Latin languages at first has happened before the Anglo-Saxon people that 
has come to England and then continues for Old English period (450-1150). The second contact has happened indirectly, but through the Celts people that have got relation with Latin languages for Roma's cohabitation since 43 to 410 years. Then there is a little similarity with Dutch and Indonesia in language.

Generally, Indonesian people organize English after Dutch's cohabitation in Indonesia, and after revolution this contact happened because the cultural contact between the people that have used English and Indonesian languages. Besides that, through knowledge English also has got relation with Indonesia language. English influences much Indonesia knowledge. Finally, as a consequence, many Indonesian people can dominate this English language. The position of English will be shift of position of Dutch. Before independence revolution, Dutch as foreign language became popular in groups of Indonesian people. English is occupied this place. So, English is cohabitation in Indonesia which English as the second language, even now English as the first foreign language in Indonesia, because as known English has been popular in educational environment.

\section{Loanwords}

There are three types of loans or borrowed elements into a number of classes depending on phonological and semantics characteristics (Field 2002) as follows: (1) loanword (serapan penuh), (2) loanblend (serapan sebagian), dan (3) loanshift (serapan terjemahan).

The process of borowing is transferred from the one language or origin into other languages. In the term, the mention of loanword is called donor, while the recipient language is called model. Loanword according to Haugen (1992: 286) is a reproduction that is attempted in one language about patterns that were previously found in other languages. Furthermore, according to Eddy (1989) and Sudarno (1992) suggest that loanwords as other terms that are almost the same meaning and cannot be avoided.

The loanword is an importation of form and meaning with degrees of phonological integration (all, none, or partial), and the importation of the model (the target), for example in using of the word hamburger. Indonesian people have known that hamburger is a meal or food. There is no other word beside that word used by Indonesian people, because it has not found the equivalent word yet in Indonesia language, so the whole Indonesian words adopted spelling and pronunciation which used by original forms (Field: 2002).

Cultural borrowings in Indonesian languages happened because of borrowing elements of foreign languages. Indonesia has organized language contacts with another nations, thus probably Indonesian languages has borrowed 
so many elements of foreign languages, for example the word khusus from Arabic language, lemari from Portuguese, and kamar from Dutch. Cultural borrowings have pointed what it is learned by other state. By the end, English lexical borrowings almost from French, such as woman's dress, and also English are borrowed by German, such as kinds of food (frankfurter, wiener, hamburger, pretzel, lager beer), and sport terms, such as match, golf, baseball, football, and rugby.

There are two conditions of motivation for borrowing why one language borrows other language Hockett (1958: 404-405) has pointed, such as: (1) Prestige motive, there is a wish for prestige looks. The people whom they admire are in speechpattern as well as in other respect. Perhaps, it is constantly in dialect borrowing, it becomes important in language borrowings only under special condition, and the prestige factor leads to extensive borrowings from the dominant languages into

\section{RESEARCH FINDINGS}

\section{Data Description}

In this description of data, the writer discuses English lexical borrowings taken from three magazines of tourism; they are Intisari ,Tamasya and Jalan-jalan. Intisari is a life style magazine that also contains many tourism and non-dominant one; (2) need-filling motive, there is a need for human necessity to identify something. The other motive for borrowing is to fill a gap among borrowing idiolects, as immigrants to the United States in the last seventy-five years that have drawn heavily on English for new words, partly on the prestige basis and partly for need-filling purpose. Two motives must often be mingled. We cannot always say which is more important in giving the instance. In exchange, however, American English has acquired only a sparse scattering of need-filling loans from the various languages of the immigrants; hamburger, wiener from immigrant German, tortilla from Mexican Spanish, spaghetti, pizza, grinder (sandwich) from Italian. Those examples of borrowing under the need-filling motive have been of borrowing from one language, but the same many variety borrowings take place constantly among dialect of a single language.

traveling articles. Tamasya is a tour and life style special media. And then, Jalan-jalan itself is the magazine that consists of traveling, hotel and restaurant rubric. Therefore, the writer tries to make tabulation of collected data through the following: 


\begin{tabular}{|c|c|c|c|c|}
\hline \multirow[t]{2}{*}{ No. } & \multicolumn{2}{|c|}{ Words } & \multirow{2}{*}{$\begin{array}{c}\text { Types of } \\
\text { borrowing } \\
\text { Loanwords }\end{array}$} & \multirow{2}{*}{$\begin{array}{l}\text { The origin of } \\
\text { borrowed words }\end{array}$} \\
\hline & $\begin{array}{l}\text { English } \\
\text { (donor) }\end{array}$ & $\begin{array}{c}\text { Indonesian } \\
\text { (Model) }\end{array}$ & & \\
\hline 1. & Adventure & Adventur & - & Latin \& French \\
\hline 2. & Bale & Bal & - & Middle Dutch \\
\hline 3. & Buffet & Bupet/bufet & - & French \\
\hline 4. & Discotheque & Diskotik & - & French \\
\hline 5 & Dessert & Dessert & $\checkmark$ & French \\
\hline 6. & Expedition & Ekspedisi & - & English \\
\hline 7. & Check in & Cek in & - & Persia \\
\hline 8. & Check out & Cek out & - & $\begin{array}{l}\text { Arabic \& } \\
\text { French }\end{array}$ \\
\hline 9. & Club & Klub & - & Spanish \\
\hline 10. & Menu & Menu & $\checkmark$ & French \\
\hline 11. & Resort & Resor & - & Latin \\
\hline 12. & Lobby & Lobi & - & Latin \& German \\
\hline 13. & Station waiter & $\begin{array}{l}\text { Station } \\
\text { waiter }\end{array}$ & $\checkmark$ & French \\
\hline 14. & Souvenir & Suvenir & - & French \& Latin \\
\hline 15. & Café & Kafe & - & French \\
\hline 16. & Hotel & Hotel & $\checkmark$ & French \\
\hline 17. & visa & visa & $\checkmark$ & French \\
\hline 18. & Spa & Spa & $\checkmark$ & Name of French \\
\hline 19. & Catering & katering & - & $\begin{array}{l}\text { French,Latin\& } \\
\text { Mid.English }\end{array}$ \\
\hline 20. & landscape & landskip & - & Dutch \\
\hline 21. & Tourist & Turis & - & French \& Latin \\
\hline 22. & Cargo & Kargo & - & Latin \\
\hline 23. & Bar & Bar & $\checkmark$ & Earliest English \\
\hline 24. & Shelter & Shelter & $\checkmark$ & Middle English \\
\hline 25. & Speedboat & Speedboat & $\checkmark$ & Middle English \\
\hline
\end{tabular}




\section{Data Analysis}

\section{Dessert}

This word is included to loanword type, because the spelling and pronunciation in English are same as in Indonesian language; dessert. Etymologically, this word is taken from French desservir that means to clear the table-des form Latin dis, and servir that means to serve. So, it is a service of fruits or sweetmeats.

\section{Menu}

This word is loanword type, because the spelling and pronunciation in English and Indonesian language are the same. In Indonesia, there is no other word beside that word used by the people. There is no equivalent word yet, so Indonesian people adapt it entirely, including its spelling or pronunciation, and that word is still used by Indonesian people, especially in tourism field. This word is from French menu. The meaning is a list of the dishes and to be served at a dinner, supper.

\section{Station waiter}

This word is loanword, because the spelling and pronunciation are the same as in Indonesian language; station waiter. This entirely borrowed word is still used by Indonesian people in tourism field or hotel term. There are two words of this term. They are station+waiter; it is included to selfexplaining compound, especially in a hotel term. Two words cannot be disassociated from each other. The word station is a place where trains stop. As loanshift or etymologically, it is taken from French station and Latin station.

\section{Hotel}

Based on types of borrowing, this word is included into loanword type. It is borrowed from an entirely borrowing term whether in pronunciation or spelling. Etymologically, this word is taken from French hostel. The meaning is an inn, and it is same as hospital that also means an inn.

\section{Visa}

This word is loanword type. It has the same pronunciation and spelling as in Indonesia terms. It is entirely English borrowed words. This word is still used by Indonesian people, especially in tourism field for a person who will go to a foreign country, or it is usually named as a passport. Etymologically, this word is taken from a foreign language. This word is from French visa; the meaning is certificate of examination on as passport.

6. Bar

This word is loanword, because there is a similarity in spelling and pronunciation. It is borrowed entirely from English words. This word is still used by Indonesian people, especially in tourism field until now. Thus, this word is constant; the word bar is used in Indonesia and English, and it has been familiar in Indonesia, especially in tourism field as bar. Etymologically, or based on the 
loanshift, it is taken from foreign language. In the Earliest English, the meaning of this word is rod of metal or wood for fastening a gate or the like, and the application to the barrier of courts of justice, and then the meaning of bar changes. In the beginning of French, bar is from the word barre.

\section{Shelter}

Based on types of borrowing, this word is known as loanword borrowed from English entirely. It is included into importation type of loanword, because there is no other word beside that word, and it is still used by people both Indonesian and English especially in tourism field. Based on loanshift of meaning or etymologically, this word is taken from a foreign language. In the Middle English this word is sheldtrume.

\section{Speedboat}

The word speedboat is as loanword type. This word consists of two word; speed+boat. In English the meaning of this word is success and velocity. Then, in Anglo Saxon it is sped that means a hostel, success for spodiz, to succed with suffix - diz, and in Dutch spoed that meaning is to succeed. While, the word boat is taken from the Middle English boot, thus that word is borrowed from Anglo Saxon that means a motor.

\section{Spa}

At first, the word spa looks as abbreviation. But, it is actually not abbreviation; because this word is especially for a tool of beauty keep.
Based on types of borrowing, this word as loanword type is borrowed from the origins of English word or it can be included into importation. Etymologically, this word is from the name of French; it is called common words from proper names, Spa of a watering place in the province of liege, Belgium, noted for its curative mineral springs.

\section{CONCLUSION}

After analyzing research findings, the writer would like to describe a conclusion about English lexical loanwords in Indonesian in tourism magazines. It can be found that 9 words borrowed from English known as loanword type. Indonesian people still use them especially in tourism field; they are bar, dessert, station waiter, hotel, shelter, spa, теnu, speedboat, and visa. After knowing the meaning of the data loanwords, the writer can classifies those terms as follows: (1) Traveling: visa and speedboat; (2) Hotel: station waiter, hotel, and shelter; (3) Restaurant: bar, dessert, and menu; (4) Lifestyle: spa. English lexical borrowings into Indonesian languages are really needed by Indonesian people, because there are not enough Indonesian word equivalents to say those terms in tourism field. Indonesian people used the English lexical loanwords because of the prestige motive and more prestigious than using Indonesian words. 


\section{REFERENCES}

Akmajian Andrian \& A. Demers Richard. 1995. Linguistics, an Introduction Language and Communication, England: Masachusetts.

Baugh Albert, C, 1935. History of the English Language, USA: D. Appleton Century Company, Inc.

Eddy, Nyoman Tusthi. 1989. Unsur Serapan Bahasa Asing dalam Bahasa Indonesia: Tinjauan Kesejarahan dan Perkembangannya. Ende: Nusa Indah.

Fromkin Victoria \& Rodman Robert, An Introduction to Language, Florida: Harcourt Brace \& Company.

Haliday, M.A.K., 1968. The User and Use of Language, in Fishman, Joshua. A., Reading in Sociology of Language, Hague: Mouton \& Company.

Hockett, F. Charles, 1958. a Course Modern Linguistics, New York: The Macmillan Company.

Hudson, R.A., 1980.Sociolinguistics, London: Cambridge University Press.

Mackey, William, F., 1968. the Description of Bilingualism, in Fishman, Joshua, A., (ed), Reading in Sociology of Language, Hague: Mouton \& Company.

Mestrhrie Rajend, 2001. Concise Encyclopedia of Sociolinguistics, in P. Muhlhausler, Jargons, New York: Elsevier/Pergaman.

Samsuri, 1981. Analisa Bahasa, Jakarta: Erlangga.
Skeat, W.W., 1953. Etymological Dictionary of the English Language, Oxford: The Clarendon Press.

Sudarno. 1992. Kata Serapan dari Bahasa Arab. Jakarta : Arikha Media Cipta.

Wardhaugh Ronald, 1986. An Introduction Sociolinguistics, Oxford: Basil Blackwell.

W. Field, Fedric, foreward by Comrie Bernard, 2002. Linguistic Borrowing in Bilingual Contexts, Amsterdam: John Benjamin Publishing Company. 